ISSN 0258-7122

Bangladesh J. Agril. Res. 34(2) : 239-245, June 2009

\title{
RESPONSE OF GARLIC TO ZINC, BORON AND POULTRY MANURE APPLICATION
}

\author{
S. NASREEN ${ }^{1}$, M. N. YOUSUF ${ }^{2}$, A. N. M. MAMUN ${ }^{3}$ \\ S. BRAHMA ${ }^{4}$ AND M. M. HAQUC ${ }^{5}$
}

\begin{abstract}
Response of garlic (var. BARI Garlic-2) to zinc, boron, and poultry manure application along with a blanket dose of $150 \mathrm{~kg} \mathrm{~N}, 50 \mathrm{~kg}$ P, $100 \mathrm{~kg} \mathrm{~K}$, and $40 \mathrm{~kg}$ S/ha was evaluated through field trials in the Grey Terrace Soil under AEZ 25 (Level Barind Tract) at Spices Research Centre, Bogra during two consecutive rahi seasons (2005-2006 and 2006-2007). Application of zinc, boron, and poultry manure significantly had increased plant height, number of leaves/plant, cloves/bulb, diameter, and weight of bulb and yield/ha in both years. The highest bulb yields of 6.10 t/ha in 2005-2006 and 6.23 t/ha in 2006-2007 were obtained from the $\mathrm{Zn}_{5} \mathrm{~B}_{1} \mathrm{~kg} / \mathrm{ha}$ plus $5 \mathrm{t} /$ ha poultry manure treatment and it was significantly higher over all other treatments. Next to it, the treatment $Z_{5} B_{1}$ $\mathrm{kg} /$ ha plus $2.5 \mathrm{t} / \mathrm{ha}$ poultry manure gave the highest bulb yield (5.99 t/ha in 2005-2006 and 6.00 t/ha in 2006-2007). The highest gross margin of Tk. 230594/ha in 2005-2006 and Tk. 234095/ha in 2006-2007 along with lower marginal rate of return (65 and 163\%) were obtained with $\mathrm{Zn}_{5} \mathrm{~B}_{1} \mathrm{~kg} /$ ha plus 5 t/ha poultry manure treatment. This treatment was not economical because of the higher cost involvement. Application of $\mathrm{Zn}$ at $5 \mathrm{~kg} / \mathrm{ha}$ along with blanket dose of N, P, K, and S fertilizers would be profitable (MRR of 5650\% in 2005-2006 and $1562 \%$ in 2006- 2007) for garlic cultivation in the Gray Terrace Soil of Shibgonj, Bogra.
\end{abstract}

Key Words: Garlic, zinc, boron, poultry manure.

\section{Introduction}

Garlic (Allium sativum L.) is one of the most important spice crops in Bangladesh. It is important both for its culinary and medicinal uses. The crop is cultivated in the rabi season in Bangladesh. The area and production of garlic in Bangladesh are about 26721 hectares and 102000 metric tons of bulb, respectively, with an average yield of $3.81 \mathrm{t} / \mathrm{ha}$ (BBS, 2006). The yield is very low as compared to the world average yield of $9.67 \mathrm{t} / \mathrm{ha}$ (FAO, 2002). Reasons for the low yield of garlic are mainly due to depletion of macro and micronutrients from the soil, use of low yielding varieties with low or no inputs and poor management practices. Farmers of Bangladesh are mostly habituated with

${ }^{1}$ Principal Scientific Officer, Horticulture Research Centre, BARI, Joydebpur, Gazipur1701, ${ }^{2}$ Scientific Officer and ${ }^{4}$ Senior Scientific Officer, Spices Research Centre, BARI, Bogra, ${ }^{3}$ Scientific Officer and ${ }^{5}$ Senior Scientific Officer, Regional Spices Research Centre, BARI, Joydebpur, Gazipur-1701, Bangladesh. 
the use of macro-nutrients, especially nitrogen, phosphorus, and potassium for crop production. Use of micro-nutrients is limited. Boron is one of the most important micro-nutrients, although it is required in very small quantity. The nutrient is important in cell division, nitrogen and carbohydrate metabolism and water relation in plant growth (Brady, 1990). Application of boron can increase bulb size, number of cloves/bulb and yield of garlic (Ahmed, 1998) and onion (Smriti et al., 2002). Response of onion to zinc application is also evident (Lal and Maurya, 1981). In addition to N, P, K, S, Zn, and B application of poultry/organic manure can increase the efficiency of chemical fertilizers and also improve the soil condition for the production of crops (Bhuiyan, 1994). However, information on the use of poultry manure in combination with inorganic fertilizers for garlic is scanty in Bangladesh. Therefore, an attempt was made to study the response of garlic to zinc, boron, and poultry manure application in presence of N, P, K, and S in Grey Terrace Soil of Shibgonj, Bogra.

\section{Materials and Method}

Field experiments were conducted at Spices Research Centre, Shibgonj, Bogra during rabi seasons of 2005-2006 and 2006-2007. Soil analysis (0-15 cm depth) was done by following ASI method (Hunter, 1984). The initial soil characteristics are presented in Table 1.

Table 1. Initial soil characteristics.

\begin{tabular}{|c|c|c|c|c|c|c|c|c|c|c|c|}
\hline \multirow{2}{*}{ Sample } & \multirow{2}{*}{$\mathrm{pH}$} & \multirow{2}{*}{$\begin{array}{l}\text { OM } \\
(\%)\end{array}$} & \multicolumn{3}{|c|}{ meq/100g } & \multirow{2}{*}{$\begin{array}{c}\text { Total } \\
\text { N (\%) }\end{array}$} & \multicolumn{5}{|c|}{$\mu g / g$} \\
\hline & & & $\mathrm{Ca}$ & Mg & $\mathrm{K}$ & & $\mathrm{P}$ & S & B & Mn & $\mathrm{Zn}$ \\
\hline Soil & 6.2 & 1.18 & 3.8 & 0.82 & 0.18 & 0.07 & 10 & 12 & 0.18 & 8.0 & 1.20 \\
\hline Critical level & - & - & 2.0 & 0.80 & 0.20 & - & 14 & 14 & 0.20 & 5.0 & 2.0 \\
\hline Poultry manure & 7.2 & 7.6 & 4.7 & 1.8 & 1.2 & 1.0 & 2.0 & 3.0 & 1.0 & 0.92 & 2.0 \\
\hline
\end{tabular}

The experiment was set up in a Randomized Complete Block (RCB) design with three replications. There were two levels of zinc ( 0 and $5 \mathrm{~kg} / \mathrm{ha}$ as zinc oxide), two levels of boron ( 0 and $1 \mathrm{~kg} \mathrm{~B} / \mathrm{ha}$ as boric acid), and three levels of poultry manure $(0,2.5$, and $5 \mathrm{t} / \mathrm{ha})$. Every plot except absolute control had received blanket dose of $150 \mathrm{~kg} \mathrm{~N} / \mathrm{ha}$ as urea, $50 \mathrm{~kg} \mathrm{P} / \mathrm{ha}$ as triple super phosphate (TSP), $100 \mathrm{~kg} \mathrm{~K} / \mathrm{ha}$ as muriate of potash (MoP), and $40 \mathrm{~kg} \mathrm{~S} / \mathrm{ha}$ as gypsum. The treatment combinations are shown in Table 2. The whole amount of poultry manure, TSP, MoP, gypsum, zinc oxide, boric acid, and 1/3rd urea were applied as per treatment at final land preparation. Cloves of garlic (var. BARI Garlic-2) were sown on 20 November 2005 and 21 October 2006 at a spacing of 
$20 \mathrm{~cm} \times 10 \mathrm{~cm}$. The remaining $2 / 3^{\text {rd }}$ urea was applied in two equal installments at 3 and 6 weeks after sowing (DAS). A light irrigations by sprinkler was given to the field immediately after sowing. Two more irrigations were given at 21 and 42 DAS. Intercultural operations, such as irrigation, weeding, mulching, etc. were done whenever required. The crop was harvested at its maturity. Data on the yield and yield components were recorded and statistically analyzed. Least Significant Difference (LSD) was used for comparison of the mean values. Partial budget and marginal analysis of undominated fertilizer responses on garlic yield were done following the method suggested by Elias and Karim (1984).

\section{Results and Discussion}

Data on plant height, number of leaves/plant, cloves/bulb, diameter of bulb, and weight of individual bulb are presented in Table 2. Application of zinc, boron, and poultry manure significantly increased yield attributes of garlic over control in both the years. The tallest plant, maximum number of leaves/plant, cloves/bulb, diameter and heaviest bulbs were produced by the treatment $5 \mathrm{~kg}$ $\mathrm{Zn}, 1 \mathrm{~kg} \mathrm{~B} / \mathrm{ha}$ pIus $5 \mathrm{t} / \mathrm{ha}$ of poultry manure that had led to the significantly highest yield of garlic (Table 2). The shortest plant, lowest number of leaves, cloves/bulb, smallest diameter and lowest bulbs were recorded in control treatment. The increase in bulb yield was recorded with increasing rate of poultry manure. Addition of Zn with NPKS gave 0.46 t/ha higher yield in 2005-06 and $0.16 \mathrm{t} /$ ha yield in 2006-07 over the NPKS application only. Increase in bulb yield due to added $5 \mathrm{~kg} \mathrm{Zn/ha} \mathrm{in} \mathrm{presence} \mathrm{of} \mathrm{NPKS} \mathrm{was} \mathrm{reported} \mathrm{by} \mathrm{Anwar} \mathrm{et} \mathrm{al.}$ (1996). Boron application also gave better yield of garlic in both the years. The result is in conformity with that of Chermsiri et al. (1995) and Ahmed (1998) who reported that $1 \mathrm{~kg} \mathrm{~B} / \mathrm{ha}$ gave higher bulb yield of garlic. The highest yields of garlic, $6.10 \mathrm{t} / \mathrm{ha}$ in 2005-2006 and 6.23 t/ha in 2006-2007, were recorded from the $\mathrm{Zn}_{5} \mathrm{~B}_{1} \mathrm{~kg} / \mathrm{ha}$ plus $5 \mathrm{t} /$ ha poultry manure treatment, while the lowest yield was recorded in control treatment in both the years. The second highest yields of 5.96 $\mathrm{t} / \mathrm{ha}$ in 2005-2006 and 6.00 t/ha in 2006-2007 were obtained from the $\mathrm{Zn}_{5} \mathrm{~B}_{1}$ $\mathrm{kg} / \mathrm{ha}$ plus $2.5 \mathrm{t} / \mathrm{ha}$ poultry manure treatment, which was also significantly different from $\mathrm{Zn}_{0} \mathrm{~B}_{0} \mathrm{~kg} / \mathrm{ha}+\mathrm{PM}_{5} \mathrm{t} / \mathrm{ha}, \mathrm{Zn}_{5} \mathrm{~B}_{0} \mathrm{~kg} / \mathrm{ha}$ in absence of poultry manure and $\mathrm{Zn}_{0} \mathrm{~B}_{1} \mathrm{~kg} / \mathrm{ha}$ plus no poultry manure treatments. The yield advantage of different treatments was due to better growth and development. Thus higher photosynthate accumulation in the cloves for higher leaves/plant would ensure higher cloves/bulb, large bulb diameter, and higher bulb weight. Moreover, applied zinc and boron in combination with nitrogen, phosphorus, potassium, and sulphur in presence of poultry manure undoubtedly increased the yield indicating that the soil was deficient in those nutrients. The lowest yields of garlic, $2.78 \mathrm{t} / \mathrm{ha}$ in 2005-06 and $2.83 \mathrm{t} / \mathrm{ha}$ in 2006-07, were obtained from control treatment. 
Table 2. Yield and yield contributing characters of garlic as affected by micro-nutrient fertilizer and manure treatments.

\begin{tabular}{|c|c|c|c|c|c|c|c|c|c|c|c|c|c|c|}
\hline \multicolumn{3}{|c|}{ Treatment combination } & \multicolumn{2}{|c|}{ Plant height (cm) } & \multicolumn{2}{|c|}{$\begin{array}{c}\text { Leaves/ plant } \\
\text { (no.) }\end{array}$} & \multicolumn{2}{|c|}{ Cloves/ bulb (no.) } & \multicolumn{2}{|c|}{\begin{tabular}{|c|}
$\begin{array}{c}\text { Daimeter of bulb } \\
(\mathrm{cm})\end{array}$ \\
\end{tabular}} & \multicolumn{2}{|c|}{$\begin{array}{l}\text { Wt. of individual } \\
\text { bulb (g) }\end{array}$} & \multicolumn{2}{|c|}{ Bulb yield (t/ha) } \\
\hline $\begin{array}{c}\mathrm{Zn} \\
(\mathrm{kg} / \mathrm{ha})\end{array}$ & $\begin{array}{c}\mathrm{B} \\
(\mathrm{kg} / \mathrm{ha})\end{array}$ & $\begin{array}{c}\text { Poultry manure } \\
(\mathrm{t} / \mathrm{ha})\end{array}$ & 2005-06 & $2006-07$ & 2005-06 & 2006-07 & 2005-06 & 2006-07 & 2005-06 & 2006-07 & 2005-06 & 2006-07 & 2005-06 & 2006-07 \\
\hline 0 & 0 & 0 & 54.8 & 58.1 & 6.5 & 6.7 & 22.0 & 25.7 & 3.3 & 3.5 & 14.58 & 14.77 & 5.00 & 5.57 \\
\hline 0 & 0 & 5 & 56.7 & 60.3 & 6.8 & 6.9 & 24.7 & 26.8 & 3.6 & 3.7 & 16.35 & 17.17 & 5.28 & 5.83 \\
\hline 5 & 0 & 0 & 60.0 & 58.7 & 7.4 & 6.8 & 26.3 & 26.9 & 3.7 & 3.8 & 19.03 & 18.67 & 5.46 & 5.73 \\
\hline 0 & 1 & 0 & 62.3 & 60.8 & 8.3 & 7.8 & 27.5 & 28.6 & 3.9 & 4.0 & 19.92 & 19.37 & 5.50 & 5.80 \\
\hline 5 & 1 & 2.5 & 63.8 & 60.1 & 8.7 & 7.9 & 30.0 & 30.6 & 4.3 & 4.5 & 20.51 & 20.27 & 5.96 & 6.00 \\
\hline 5 & 1 & 5 & 67.0 & 66.5 & 9.2 & 8.7 & 33.7 & 32.9 & 4.4 & 4.6 & 19.52 & 21.00 & 6.10 & 6.23 \\
\hline 5 & 1 & 0 & 60.1 & 61.2 & 7.5 & 7.2 & 28.3 & 29.8 & 3.8 & 4.1 & 1094 & 19.66 & 5.90 & 5.93 \\
\hline \multicolumn{3}{|c|}{ Control (native nutrient) } & 48.0 & 50.6 & 5.3 & 5.5 & 16.8 & 18.9 & 2.4 & 2.8 & 1.17 & 11.27 & 2.78 & 2.83 \\
\hline \multicolumn{3}{|c|}{$\operatorname{LSD}(0.05)$} & 2.8 & 1.1 & 0.5 & 0.2 & 1.9 & 0.4 & 0.3 & 01 & 5.7 & 0.30 & 0.14 & 0.12 \\
\hline \multicolumn{3}{|c|}{ CV (\%) } & 4.5 & 6.2 & 4.0 & 5.8 & 5.0 & 6.2 & 5.3 & 7.0 & 5.7 & 6.5 & 6.0 & 8.0 \\
\hline
\end{tabular}


Table 3. Partial budget and dominance analysis for different treatments.

\begin{tabular}{|c|c|c|c|c|c|c|c|c|c|c|c|}
\hline \multicolumn{3}{|c|}{ Treatment combination } & \multicolumn{2}{|c|}{ Bulb yield (kgh/ha } & \multicolumn{2}{|c|}{ Gross return (Tk./ha) } & \multicolumn{2}{|c|}{ Cost of fertilizer (Tk./ha) } & \multicolumn{2}{|c|}{ Gross margin (Tk./ha) } & \multirow[t]{2}{*}{ Remarks } \\
\hline Zn (kg/ha) & $\begin{array}{c}\text { B } \\
(\mathrm{kg} / \mathrm{ha})\end{array}$ & $\begin{array}{l}\text { Poultry manure } \\
\text { (t/ha) }\end{array}$ & 2005-2006 & $2006-2007$ & 2005-2006 & 2005-2006 & 2006-2007 & 2005-2006 & 2006-2007 & $2005-2006$ & \\
\hline 0 & 0 & 0 & 5000 & 5570 & 200000 & 222800 & 8850 & 9000 & 191150 & 213800 & CUD \\
\hline 0 & 0 & 5 & 5280 & 5830 & 211200 & 233200 & 11850 & 12500 & 199350 & 220700 & CD \\
\hline 5 & 0 & 0 & 5460 & 5730 & 218400 & 229200 & 9170 & 9385 & 209230 & 219815 & CUD \\
\hline 0 & 1 & 0 & 5500 & 5800 & 220000 & 232000 & 9268 & 9470 & 210732 & 222530 & CD \\
\hline 5 & 1 & 2.5 & 5960 & 6000 & 238400 & 240000 & 10006 & 11605 & 228394 & 228395 & CUD \\
\hline 5 & 1 & 5 & 6100 & 6230 & 244000 & 249200 & 13406 & 15105 & 230594 & 234095 & CUD \\
\hline 5 & 1 & 0 & 5900 & 5930 & 236000 & 237200 & 9688 & 9855 & 226312 & 227345 & CD \\
\hline Control (na & ive nutrie & & 2780 & 2830 & 111200 & 113200 & 0 & 0 & 111200 & 113200 & CUD \\
\hline
\end{tabular}

$\mathrm{CD}=$ Cost dominated, $\mathrm{CUD}=$ Cost undominated

Table 4. Marginal analysis of cost undominated fertilizer response to the bulb yield of garlic.

\begin{tabular}{|c|c|c|c|c|c|c|c|c|c|c|c|c|}
\hline \multicolumn{3}{|c|}{ Treatment combination } & \multicolumn{2}{|c|}{ Gross return (Tk./ha) } & \multicolumn{2}{|c|}{$\begin{array}{c}\text { Variable cost } \\
\text { (fertilizer cost only) } \\
(\mathrm{Tk} . / \mathrm{ha})\end{array}$} & \multicolumn{2}{|c|}{$\begin{array}{c}\text { Marginal increase in } \\
\text { gross margin } \\
\text { (Tk./ha) }\end{array}$} & \multicolumn{2}{|c|}{$\begin{array}{c}\text { Marginal increase in } \\
\text { variable cost (Tk./ha) }\end{array}$} & \multicolumn{2}{|c|}{$\begin{array}{l}\text { Marginal rate of } \\
\text { return, MRR (\%) }\end{array}$} \\
\hline $\begin{array}{c}\mathrm{Zn} \\
(\mathrm{kg} / \mathrm{ha})\end{array}$ & B (kg/ha) & $\begin{array}{c}\text { Poulty manure } \\
(\mathrm{kg} / \mathrm{ha})\end{array}$ & 2005-06 & 2006-07 & 2005-06 & 2006-07 & 2005-06 & 2006-07 & 2005-06 & $2006-07$ & 2005-06 & 2006-07 \\
\hline 5 & 1 & 5000 & 230594 & 234095 & 13406 & 15105 & 2200 & 5700 & 3400 & 3500 & 65 & 163 \\
\hline 5 & 1 & 2500 & 228394 & 228395 & 10006 & 11605 & 19164 & 8580 & 836 & 2220 & 2292 & 386 \\
\hline 5 & 0 & 0 & 209230 & 219815 & 9170 & 9385 & 18080 & 6015 & 320 & 385 & 5650 & 1562 \\
\hline 0 & 0 & 0 & 1911580 & 213800 & 8850 & 9000 & 79650 & 100600 & 8850 & 9000 & 903 & 1118 \\
\hline \multicolumn{3}{|c|}{ Control (native nutrient } & 111200 & 113200 & 0 & 0 & - & - & - & - & - & - \\
\hline
\end{tabular}




\section{Economic evaluation}

In order to identify an economically viable treatment combination, partial budget, and dominance analysis followed by marginal analysis of cost undominated treatments was done. Gross return was calculated from the price of garlic. Variable costs ere calculated from the costs of fertilizer used. Partial budget analysis of fertilizer use revealed that the highest gross margin of Tk. 230594 in 2005-2006 and Tk. 234059/ha in 2006-2007 along with lower marginal rate of return (65 and 163\%) were obtained from $\mathrm{Zn}_{5} \mathrm{~B}_{1} \mathrm{~kg} /$ ha plus $2.5 \mathrm{t} \mathrm{PM} / \mathrm{ha}$ and $\mathrm{Zn}_{5}$ $\mathrm{B}_{1} \mathrm{~kg} / \mathrm{ha}$ plus $5 \mathrm{t} \mathrm{PM} / \mathrm{ha}$ treatment (Table 3). Though the treatments $\mathrm{Zn}_{5} \mathrm{~B}_{1} \mathrm{~kg} / \mathrm{ha}$ plus $2.5 \mathrm{t} / \mathrm{ha} \mathrm{PM}$ and $\mathrm{Zn}_{5} \mathrm{~B}_{1} \mathrm{~kg} / \mathrm{ha}$ plus $5 \mathrm{t} \mathrm{PM} /$ ha gave the highest yield of garlic as well as gross margin, these two treatments were not profitable because of high cost investment. Dominance analysis shows that the treatment $\mathrm{Zn}_{0} \mathrm{~B}_{0} \mathrm{~kg} / \mathrm{ha}+5 \mathrm{t}$ $\mathrm{PM} / \mathrm{ha}$. $\mathrm{Zn}_{0} \mathrm{~B}_{1} \mathrm{~kg} / \mathrm{ha}+\mathrm{PM}_{0} \mathrm{t} / \mathrm{ha}$ and $\mathrm{Zn}_{5} \mathrm{~B}_{1} \mathrm{~kg} / \mathrm{ha} \mathrm{PM}_{0} \mathrm{t} / \mathrm{ha}$ were cost dominated. Marginal analysis showed that the maximum marginal rate of return (MMR) $5650 \%$ in $2005-2006$ and $1562 \%$ in 2006-2007 were obtained when the crop was fertilized with $\mathrm{Zn}$ only (Table 4). Similar result was reported for garlic by Nasreen et al. (2007).

\section{Conclusion}

The study revealed that application of fertilizer at the rate of $150 \mathrm{~kg} \mathrm{~N}, 50 \mathrm{~kg} \mathrm{P}$, $100 \mathrm{~kg} \mathrm{~K}, 40 \mathrm{~kg} \mathrm{~S}$, and $5 \mathrm{~kg} \mathrm{Zn/ha} \mathrm{would} \mathrm{be} \mathrm{economical} \mathrm{for} \mathrm{higher} \mathrm{garlic}$ production in Grey Terrace Soil of Shibgonj, Bogra.

\section{References}

Ahmed, S. 1998. Effect of Zn, Cu, B and S on the growth and yield of garlic. MS Thesis, Dept. of Horticulture, Bangladesh Agricultural University, Mymensingh. P. 75.

Anwar, M. N., M. S. Huq, M. J. U. Sarker. S. K. Nandy and M. S. Islam. 1996. Effects of nitrogen, phosphorus, potassium, sulphur and zinc on garlic. Bangladesh Hort. 24 (1\&2): $12-16$.

Bangladesh Bureau of Statistics (BBS). 2006. Statistical Year Book of Bangladesh. Bangladesh Bureau of Statistics, Ministry of Planning. Government oF the Peoples' Republic of Bangladesh, Dhaka p. 145.

Bhuiyan, N.J. 1994. Crop production trends and need of sustainability in Agriculture. Paper presented at the workshop on 'Integrated Nutrient Management for Sustainable Agriculture, held at SRDI, Dhaka, June 26-28. 1994.

Brady, N.C. 1990. The nature and properties and soils. 10th edition, A.K. Ghosh. Printing-Hall of India Pvt. Ltd., New Delhi. p. 383.

Chermsiri, C., H. Watanable, S. Attajarusit. J. Tuntiwarawit and S. Kaewaroj. 1995. Effect of boron sources on garlic (Alliuni sativum L. ) productivity. Biol. Fert. Soils. 20(2): 125-129. 
Elias. S. M. and R. Karim. 1984. Application of partial budget technique in cropping system research at Chittagong. AEER No. 10 April, Econ. I)iv.. BARI, Gazipur. pp. 75-8 1

FAO. 2002. Production Yearbook. Basic Data Branch. Statistics Division, Food and Agricultural Organization, Rome, Italy 56: 157.

Hunter, A.H. 1984. Soil Fertility Analytical Services in Bangladesh. BARC/lAI)S Consultancy Rep. Contract Aid 388-0051.

Lal. S. and A. N. Maurya. 1981. Effect of zinc on onion. Haryana J. Hort. Sci. 10: 231235.

Nasreen, S., M. A. Hossain and A. T. M. Farid. 2007. Integrated nutrient management for garlic (Alhum cepa L.). Bangladesh J. Agril. Sci. 34(1): 45-48.

Shahidullah, M., F. Huq., M. A. Karirn and R. K. Mondal. 1990. Influence of NPK on the growth, yield attributes, yield and biochemical parameters of garlic. Bangladesh $J$. Agric. Res. 15: 11-15.

Smriti. S., R. Kumar and S. K. Singh. 2002. Effect of sulphur and boron nutrition on growth, yield and quality of onion (Alhum cepa L.). J. Appl. Biol. 12: 40-46. 